\title{
EDITORIAL
}

\section{'Professor Galveston' has departed. Obituary - Daniel Traber}

\author{
Donald S Prough, Perenlei Enhkbaatar and Csaba Szabo*
}

Daniel L Traber, PhD (Figure 1), an alumnus and longtime faculty member at University of Texas Medical Branch (UTMB), passed away on 19 September 2012 after a 2-year illness. A quintessential translational scientist, Dr Traber served on the UTMB faculty for over 50 years - most recently as the Charles Robert Allen Professor of Anesthesiology, Professor of Neuroscience and Cell Biology, and Director of the Investigational Intensive Care Unit. He had previously served as Chief of Anesthesia Research and Coordinator of Research at the Shriners Burns Institute.

Dan earned his MA degree in Physiology and Biochemistry (1962) and his PhD degree in Physiology and Pharmacology (1965) from UTMB. After completing a postdoctoral fellowship in Pharmacology at Ohio State University, College of Medicine, Dr Traber joined the UTMB faculty in 1966 and, except for sabbatical leaves, remained on the active faculty until his death His sabbaticals included several highly productive visits to the Ludwig Boltzmann Institute in Vienna, Austria to work with the prominent critical care scientist Günther Schlag.

To say that Dan's research attained a national and international reputation is an understatement. He was a vital force in critical care research, serving as a Charter Member and Past President of the Shock Society, and a past and present member of most Editorial Boards in physiology and critical care. Dan impressed everyone with his integrity, incredible vitality, and insatiable scientific curiosity. His early research defined some of the basic hemodynamic and neuroendocrine and homeostatic mechanisms of critical illness. Subsequently, his large-animal models of critical illness became gold standards in the field. They served a vital role in critical care research, providing a unique and clinically relevant test bed to explore and expand on concepts of shock, sepsis, acute lung injury, burn injury, wound healing, and

*Correspondence: csszabo@utmb.edu

Department of Anesthesiology, University of Texas Medical Branch,

601 Harborside Drive, Galveston, TX 77555-1102, USA

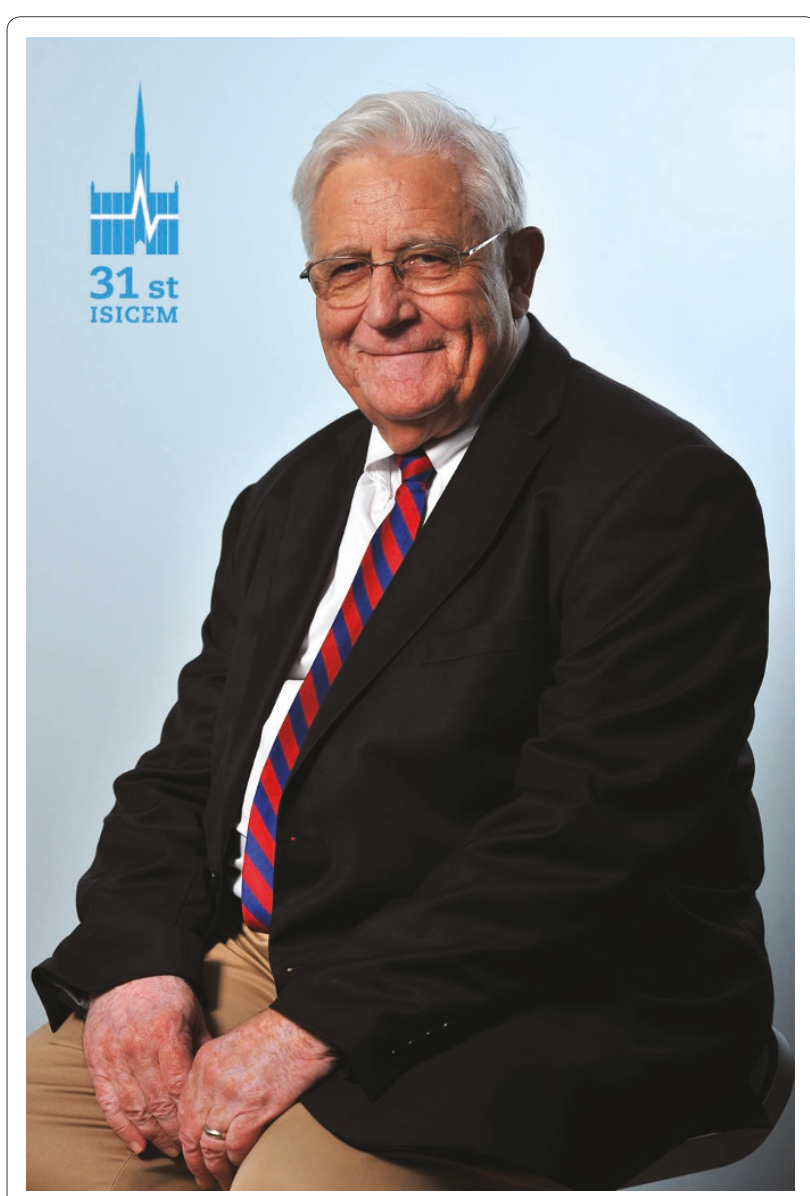

Figure 1. Daniel L Traber, PhD

the evaluation of novel therapeutic approaches as they progressed toward clinical testing. The pathways Dan investigated ranged from novel anesthetics, to prostanoid modulators, to modulators of oxidative and nitrative stress, to coagulation cascades, and to vasopressin receptor modulators. Dan not only acted as the scientific core of his own research group at UTMB, but he was a rock-solid collaborator to many scientists worldwide. Over his 53-year scientific career, he authored nearly 500 scientific articles. He served as a principal or coinvestigator in innumerable major federal and foundation grants. 
Dan had a ubiquitous presence at scientific meetings, where he was famous for his high-energy, straightforward, and engaging presentation style, as well as his incredible imagination and precision during the discussions. There were no taboos for him; he was never afraid to take sides in scientific matters, regardless of what was fashionable or what dogma the authorities held. If a scientific concept was shaky, Dan was the first to declare that the 'king was undressed'. In his typical style, he would stand up, and start his comments with 'Traber, Galveston' This, by the way, sometimes resulted in slight misunderstandings with junior researchers, who addressed him subsequently as 'Professor Galveston', believing that his first name was Traber and his last name was Galveston.

Dan mentored over 100 young scientists from many different countries; those who listened and learned the most tended to be the ones who later became most successful in establishing their own independent scientific careers. This 'Traber Army' continues to make important contributions to medical research and clinical practice, directly helping millions of patients throughout the world.

Dan had an encyclopedic knowledge not only of physiology and pathophysiology, but of the history of medicine as well; his legendary 'history of physiology' lectures will be long remembered. His knowledge of European history closely resembled his scientific knowledge.

Dan loved an anecdote or a good joke almost as much as he loved science. At dinner conversations, one had to switch back and forth between cracking up and marveling at the depth and originality of his life philosophy. Experiencing his skills as a singer (bass soloist) was another rare treat.

As successful as he was, he remained modest and down-to-earth almost to a fault. He was generous with his time; he was ready to discuss critical care concepts with anybody in the department - and what a treat were they in for! Dan not only knew his integrative physiology like nobody else, but had an uncanny ability to cut away the fluff in order to get down to the bottom of any concept.

Dan remained a straight shooter and a force of nature all the way until the very end. He used to say: 'Why retire? If you can do your hobby all of your life, why would you stop doing it?' Only the future interested him. In fact, he received a letter of notification of award on a new 5-year grant 1 day before he passed away at age 74 . It was deeply touching to witness him discussing the details of this new project and other new concepts with his mentees until the last hours of his life.

Another irreplaceable member of a rare generation of critical care physiologists has thus departed. They just do not make them like they used to. Dan's departure leaves an amazing research legacy. However, his mission will continue and be carried on for many years to come by his colleagues, former students, and friends.

He leaves a wife Lillian (who happens to be much more than a wife, but a longstanding laboratory manager, scientific collaborator, and co-author as well), a son, and a large extended family consisting of former trainees, disciples, and collaborators. We will all miss him deeply. And the 'Traber Army' will soldier on.

Abbreviations

UTMB, University of Texas Medical Branch.

\section{Competing interests}

The authors declare that they have no competing interests.

Published: 8 November 2012

doi:10.1186/cc11810

Cite this article as: Prough DS, et al.: Professor Galveston' has departed. Obituary - Daniel Traber. Critical Care 2012, 16:169. 